\title{
Relationships between Manicina areolata (Cnidaria: Scleractinia), Thalassia testudinum (Anthophyta) and Neogoniolithon sp. (Rhodophyta)
}

\author{
Miguel A. Ruiz-Zárate ${ }^{1}$, Julio Espinoza-Avalos ${ }^{1, *}{ }^{,}$Juan P. Carricart-Ganivet $^{1}$, \\ Dalila Fragoso ${ }^{2}$
}

${ }^{1}$ El Colegio de la Frontera Sur, Apdo. Postal 424, Chetumal, Quintana Roo 77000, Mexico

${ }^{2}$ Laboratorio de Ficología, Facultad de Ciencias, UNAM, Apdo. Postal 70-620, Ciudad Universitaria, Mexico D.F. 04510, Mexico

\begin{abstract}
The free-living coral Manicina areolata, the seagrass Thalassia testudinum, and the coralline algae Neogoniolithon sp. co-occur in the reef lagoon of Xahuayxol, Quintana Roo, in the Mexican Caribbean. The distribution and abundance of these organisms was measured. In order to study why the coral was distributed only within the medium-density stands of $T$. testudinum, but not in the high- or low- density stands of the seagrass, 3 size classes of $M$. areolata were transplanted into 3 naturally occurring seagrass densities. Mortality, displacement, righting reaction, zooxanthellae, mitotic index, and chlorophyll a were evaluated for the transplanted colonies. High mortality of $M$. areolata was recorded in the low-density zone of T. testudinum, attributable to siltation and predation, whereas in the high-density zone of this seagrass, the coral was under stress, as indicated by a lowered zooxanthellae density. The fragile, arborescent algae Neogoniolithon sp. was found distributed only within the medium-density zone of $T$. testudinum, and $M$. areolata selectively recruited onto that algae. Experiments in which the coral and algae were separated in the medium-density seagrass zone demonstrated that Neogoniolithon sp. offers M. areolata adaptive and ecological advantages: its survivorship was significantly higher when attached to the algae than when this substrate was not available. Because of the natural distribution of Neogoniolithon sp., the coral did not recruit in zones that would cause it stress, or even death. M. areolata and Neogoniolithon sp. eventually separate because of the increase in size (and weight) of the coral, and the fragility of the algae. Thus, the distribution of Neogoniolithon sp. explained the distribution of $M$. areolata instead of the high negative correlation found between the density of $T$. testudinum and the coral.
\end{abstract}

KEY WORDS: Recruitment $\cdot$ Corals $\cdot$ Coralline algae $\cdot$ Seagrasses $\cdot$ Caribbean $\cdot$ Mexico $\cdot$ Yucatan Peninsula

\section{INTRODUCTION}

The free-living colonies of Manicina areolata (Linnaeus), a zooxanthellate scleractinian, are found in the Caribbean Sea, mainly associated with seagrass beds, especially Thalassia testudinum Banks ex König (Johnson 1988). Diverse aspects of its biology, ecology and evolution have been studied (Goreau \& Goreau

*Corresponding author. E-mail: jespino@ecosur-qroo.mx
1960, Peters et al. 1981, Johnson 1988, 1992a,b, Johnson et al. 1995). However, it is not known what ecological factors control its relationship with seagrasses.

The larval settlement of sessile organisms requires solid surfaces with precise physical and biological characteristics, such as substrate angle, wave exposure and surface area, which in turn can clearly affect juvenile survivorship and morphogenesis. In contrast, freeliving organisms (such as Manicina areolata) require a firm substrate only for initial growth stages; hence, sur- 
face characteristics are almost circumstantial and do not control their morphogenesis (Hadfield 1986). However, in several laboratory- and field-oriented studies it has been found that the settlement and larval metamorphosis of different marine organisms occur in response to specific chemical signals produced by marine macroalgae (Kato et al. 1975, Switzer-Dunlap 1978, Trapido-Rosenthal \& Morse 1986, Pawlik 1989). For example, a complex polysaccharide found in the crustose coralline rhodophyte Hydrolithon boergesenii (Foslie) Foslie specifically induces larval settlement and metamorphosis in the scleractinian corals Agaricia humilis Verril and A. tenuifolia Dana (Morse 1992, Morse \& Morse 1996).

In the current work, the distribution, density, and size of Manicina areolata and Thalassia testudinum were studied at Xahuayxol, a coral reef area of the Mexican Caribbean. Three size classes of the coral (juvenile, and 2 presumed adult classes) were transplanted into 3 density zones of $T$. testudinum (low, medium, and high density), in order to determine the mortality and displacement of $M$. areolata in each zone. Zooxanthellae density, along with mitotic indices and chlorophyll a ( $\mathrm{chl} \mathrm{a)} \mathrm{concentrations} \mathrm{in} \mathrm{isolated}$ zooxanthellae were measured to evaluate the responses of $M$. areolata to the transplantation. Such measurements have been used to describe changes in the general condition of corals (Brown \& Howard 1985, Brown 1988, Grigg \& Dollar 1990, Jones 1997, Mattia 1997). Another experiment was designed to evaluate the righting reaction of 3 size classes of $M$. areolata. Finally, the importance of the coralline algae Neogoniolithon sp. for the survivorship of $M$. areolata was investigated after it became evident that this coral recruits preferentially on Neogoniolithon sp.

\section{MATERIALS AND METHODS}

Study area. Xahuayxol is located at $18^{\circ} 30^{\prime} 15^{\prime \prime} \mathrm{N}$, $87^{\circ} 45^{\prime} 32^{\prime \prime} \mathrm{W}$, in the southern region of Quintana Roo, Mexico. It is bordered by a reef that is divided into 6 zones. These include a reef lagoon that is 250 to $300 \mathrm{~m}$ wide and has a maximum depth of $2.3 \mathrm{~m}$ (Fig. 1). A seagrass meadow of approximately $100 \mathrm{~m}$ width is located immediately seaward of a 1 to $2 \mathrm{~m}$ wide band of Halodule wrightii Ascherson along the shore. The meadow starts with a seagrass belt 30 to $35 \mathrm{~m}$ wide, which is mainly composed of Thalassia testudinum and Syringodium filiforme Kützing. Here, T. testudinum is larger and higher in density than in the rest of the seagrass meadow (Figs. $1 \& 2$, Table 1). Seaward of this a $25 \mathrm{~m}$ wide belt of $T$. testudinum with small blades and medium shoot density occurs (Figs. $1 \& 2$, Table 1). The population of Manicina areolata occurs only in this sea- grass belt. From 62 to $115 \mathrm{~m}$ offshore, T. testudinum increases in density but not in size (Fig. 1, Table 1). After this seagrass belt, $T$. testudinum does not change in size but exhibits a noticably low shoot density (Figs. 1 \& 2, Table 1).

Distribution, density, and size of Manicina areolata and Thalassia testudinum. Nine transects were placed at Xahuayxol, from September 29 to October 2, 1996. Each transect ran parallel to the shore and was sepa-
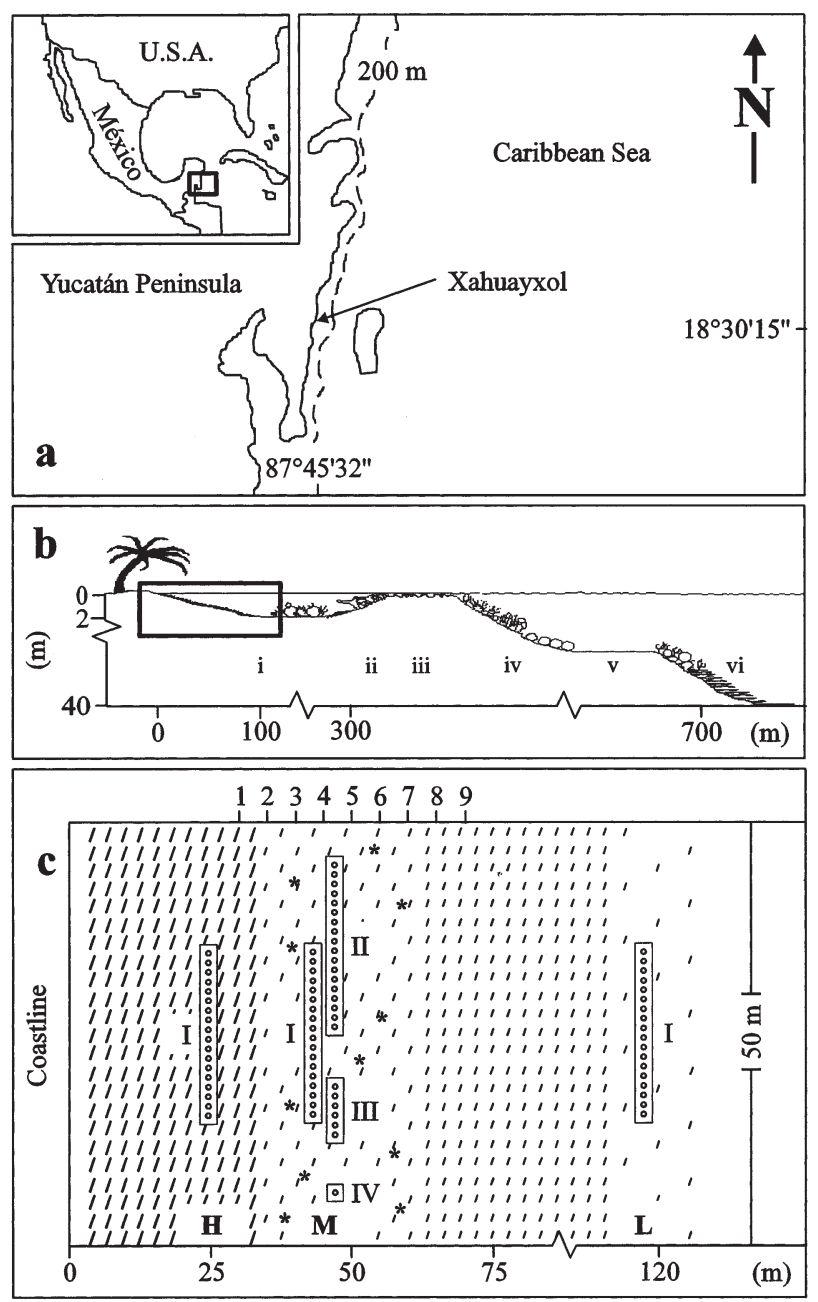

Fig. 1. (a) Location of Xahuayxol in the southern region of the Mexican Caribbean. (b) Diagrammatic profile perpendicular to the shoreline showing reef zonation at Xahuayxol: $i$, reef lagoon; ii, rear zone; iii, breaker zone; iv, fore reef; $\mathrm{v}$, sand platform; vi, buttress zone (spur and grove). (c) Diagram of the study zone, in the reef lagoon of Xahuayxol: the Arabic numerals 1 to 9 represent the transects, parallel to the coastline, where the population measurements of Manicina areolata and Thalassia testudinum were carried out. The Roman numerals I to IV correspond to the position where the 4 experiments were performed on the high $(\mathrm{H})$, medium $(\mathrm{M})$, and low (L) densities of $T$. testudinum. ( $) T$. testudinum, according to its density and size, $(*) M$. areolata colonies. See text for details. Note the difference in scale between the 2 axes 

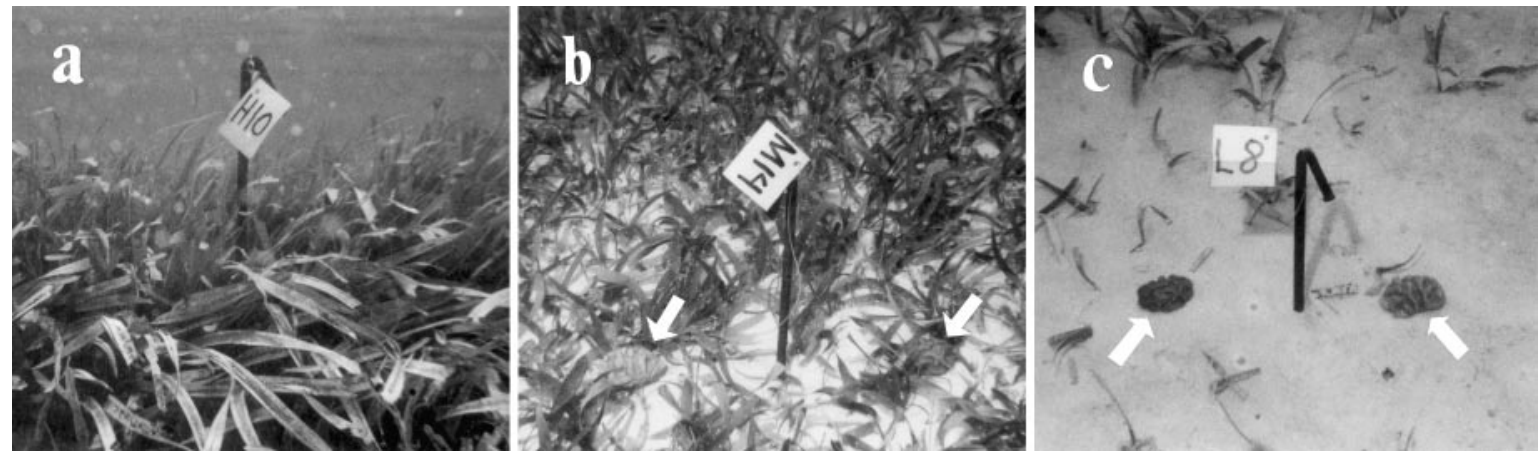

Fig. 2. Experimental zones within (a) high, (b) medium, and (c) low densities of Thalassia testudinum. Manicina areolata colonies (arrows) were placed at both sides of numbered metal stakes (see text for details). Photos by H. Bahena-Basave

rated from adjacent transects by $5 \mathrm{~m}$. Transects were 30 to $70 \mathrm{~m}$ from the coastline, at water depths of 0.83 to $1.50 \mathrm{~m}$ (Table 1). Each transect was further subdivided into 25 quadrants of $1 \mathrm{~m}^{2}$. Within each transect, the density of $M$. areolata and the length and width of each colony was measured. The shoot density and the length of 5 of the largest blades of T. testudinum and Syringodium filiforme was obtained from seven $0.0625 \mathrm{~m}^{2}$ quadrats, placed every $3 \mathrm{~m}$ along the $25 \mathrm{~m}$ transects.

The surface area $\left(\mathrm{cm}^{2}\right)$ of each colony of Manicina areolata was calculated assuming an elliptic shape for the corallum tissue portion ( $A=\pi[$ length/2][width/2]). Area cover $\left(\mathrm{cm}^{2} \mathrm{~m}^{-2}\right)$ of $M$. areolata was also calculated. An analysis of spatial pattern of colonies was made using the local quadratic variance of 2 terms method (Ludwig \& Reynolds 1988).

The length, width, height, and surface area of 73 colonies of Manicina areolata were compared in a preliminary survey. A redundant relation was found between height and length ( $\mathrm{r}=0.94, \mathrm{p}<0.0001)$, and between height and surface area $(\mathrm{r}=0.96, \mathrm{p}<0.0001)$. If $M$. areolata starts sexual reproduction when it reaches a height of 15.0 to $20.0 \mathrm{~mm}$ (Johnson 1992b), the corresponding surface area is between 3.0 and $5.8 \mathrm{~cm}^{2}$, and its length is between 2.5 and $3.5 \mathrm{~cm}$, near the $4.0 \mathrm{~cm}$ considered by Bak \& Engel (1979) and Chiaponne \& Sullivan (1996) as the limit in length for a juvenile coral colony. Accordingly, a juvenile colony of $M$. areolata was considered as those $\leq 3.5 \mathrm{~cm}$ in length. These sizes do not necessarily correspond to sexual stages since we did not look for gonad development.

Identification of the coralline algae. During the census of Manicina areolata, and while collecting colonies for the transplantation experiments (see below), it was observed that remains of a coralline alga were attached to the aboral portion of the majority of juvenile colonies. In a later sampling, it was found that $92 \%$ of 48 recruits $(<10 \mathrm{~mm})$ were attached to a free-living

Table 1. Average values of population parameters of juvenile (J) and adult (A) Manicina areolata, and of seagrasses Thalassia testudinum (Tt) and Syringodium filiforme $(\mathrm{Sf})$ at the nine $25 \mathrm{~m}$ transects parallel to the coastline of Xahuayxol, Mexico. DC $=$ dis-

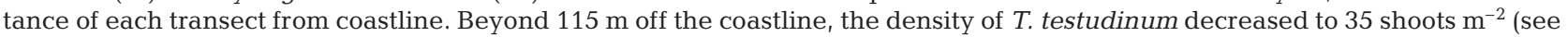
'Materials and methods' and Fig. 1)

\begin{tabular}{|c|c|c|c|c|c|c|c|c|c|c|c|c|}
\hline \multirow[t]{3}{*}{ Transect } & \multirow{3}{*}{$\begin{array}{l}\mathrm{DC} \\
(\mathrm{m})\end{array}$} & \multirow{3}{*}{$\begin{array}{c}\text { Depth } \\
\text { (m) }\end{array}$} & \multicolumn{6}{|c|}{ Manicina areolata } & \multicolumn{4}{|c|}{ Seagrasses } \\
\hline & & & \multicolumn{3}{|c|}{ Density (colonies $\mathrm{m}^{-2}$ ) } & \multicolumn{3}{|c|}{ Cover $\left(\mathrm{cm}^{2} \mathrm{~m}^{-2}\right)$} & \multicolumn{2}{|c|}{ Density (shoots $\mathrm{m}^{-2}$ ) } & \multicolumn{2}{|c|}{ Height (cm) } \\
\hline & & & $\mathrm{J}$ & A & Total & $\mathrm{J}$ & A & Total & $T t$ & Sf & $T t$ & $S f$ \\
\hline 1 & 30 & 0.8 & 0.0 & 0.0 & 0.0 & 0.0 & 0.0 & 0.0 & 541.7 & 1291.4 & 20.1 & 21.1 \\
\hline 2 & 35 & 0.9 & 0.2 & 1.0 & 1.2 & 0.8 & 15.0 & 15.8 & 317.7 & 393.1 & 11.5 & 11.2 \\
\hline 3 & 40 & 1.1 & 0.4 & 1.5 & 1.9 & 1.5 & 25.7 & 27.2 & 246.9 & 196.6 & 12.1 & 8.7 \\
\hline 4 & 45 & 1.1 & 0.6 & 1.2 & 1.8 & 1.5 & 20.9 & 22.4 & 230.9 & 331.4 & 10.6 & 10.9 \\
\hline 5 & 50 & 1.1 & 0.1 & 1.2 & 1.4 & 0.1 & 27.3 & 27.5 & 306.3 & 347.4 & 11.7 & 11.4 \\
\hline 6 & 55 & 1.2 & 0.1 & 0.6 & 0.7 & 0.6 & 14.8 & 15.3 & 406.9 & 276.6 & 12.8 & 10.6 \\
\hline 7 & 60 & 1.2 & 0.0 & 0.4 & 0.4 & 0.0 & 7.0 & 7.0 & 377.1 & 176.0 & 12.3 & 9.8 \\
\hline 8 & 65 & 1.4 & 0.0 & 0.0 & 0.0 & 0.0 & 0.0 & 0.0 & 409.1 & 374.9 & 14.0 & 11.5 \\
\hline \multirow[t]{2}{*}{9} & 70 & 1.5 & 0.0 & 0.0 & 0.0 & 0.0 & 0.0 & 0.0 & 420.6 & 260.6 & 12.9 & 9.1 \\
\hline & \multicolumn{2}{|c|}{ Average: } & 0.2 & 0.7 & 0.8 & 0.5 & 12.3 & 12.8 & 361.9 & 405.3 & 13.1 & 11.6 \\
\hline
\end{tabular}




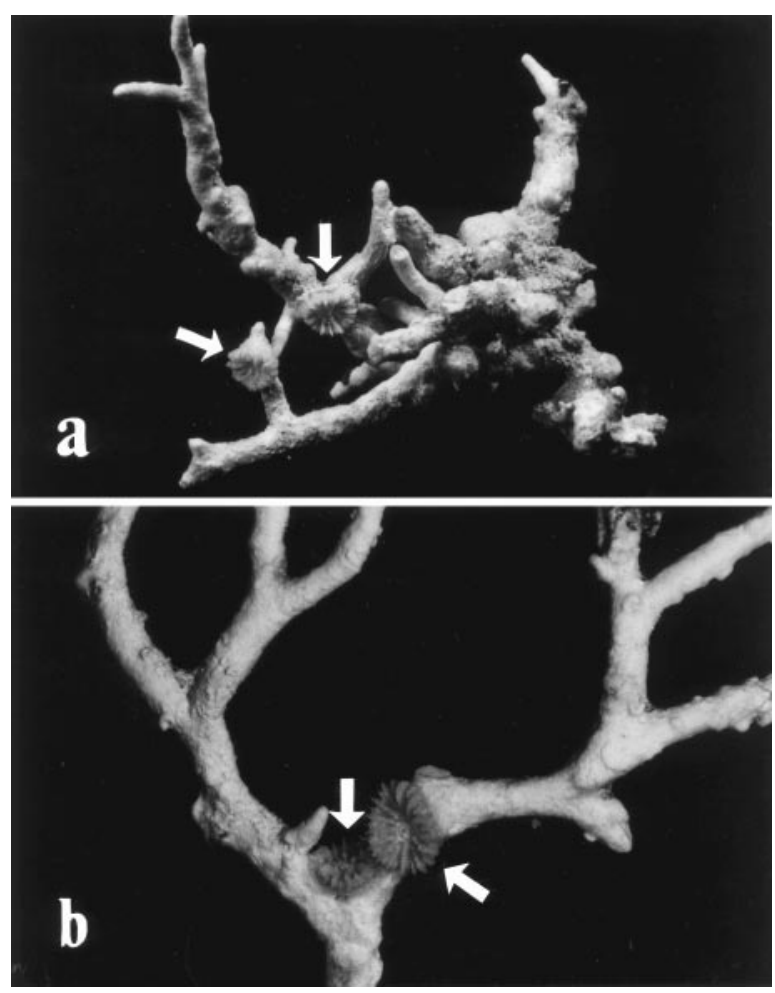

Fig. 3. Recruits of Manicina areolata (arrows) attached to Neogoniolithon sp. (a) $\times 0.5$ (catalog number ECOCHBC0148), (b) $\times 0.4$ (catalog number ECOCHBC-0146). Photos by H. Bahena-Basave

branched nongeniculated coralline alga (Fig. 3). The remaining recruits were affixed to a fragment of a stony coral, a crustose coralline algae, a bivalve shell or a piece of wire. These alternative substrates for $M$. areolata, with the exception of wire, were abundant at the study site.

The nongeniculated coralline algae that we found at Xahuayxol was consistent with species included in Neogoniolithon (Taylor 1960, Wynne 1998), but it was not possible to identify the algae to species level because the uniporated sporangial conceptacles were empty. The thallus of the species from Xahuayxol is free-living, with an agglomerated habit, up to $6 \mathrm{~cm}$ in height, and rounded tips, and is fragile, with an unclear basal structure. The branches are terete to a little complanated, with branching mainly dichotomic, generally of 1 order. Internally, a core of coaxial filaments is found, formed by elongated cells with lengths 2-3 times their width. The filaments are joined by cell fusion with no evident secondary pit-connections. No trichocytes were observed, and the cortical cells are rather quadrangular in shape.

Characterization of the experimental zones with different Thalassia testudinum density. Three seagrass-density zones were selected to perform the experiments (Fig. 1): high (542 shoots $\mathrm{m}^{-2}$, Zone H), medium (239 shoots $\mathrm{m}^{-2}$, Zone M), and low (35 shoots $\mathrm{m}^{-2}$, Zone L). The distance to the shore of each experimental zone was 25, 45 and $118 \mathrm{~m}$, with depths of 0.5 , 1.1 and $2.3 \mathrm{~m}$, respectively. A Tukey's HSD test indicated significant differences between the mean T. testudinum shoot density in the 3 experimental zones $(p<0.001)$. The measurements indicated below were carried out for each experimental zone.

Sediment: On June 15, 4 cores of sediments were collected in each zone, using a $4.4 \mathrm{~cm}$ diameter PVC tube that was inserted $10 \mathrm{~cm}$ into the substratum or sandy bottom. Different grain sizes were separated by sieving the sample (Folk 1969), and the software of Vargas-Hernández (1991) was used to calculate granulometric parameters.

Irradiance and temperature: On June 28, 1997, 15 instantaneous readings of irradiance were obtained in each zone, with a Li-Cor ${ }^{\circledR}$ LI-1000 irradiometer, by placing the spherical sensor on the bottom. It was a cloudy day. The water temperature was obtained by placing a thermometer on the substratum.

Plant biomass: Plant biomass was measured by haphazardly placing three $0.0625 \mathrm{~m}^{2}$ quadrats within each experimental zone and collecting all the enclosed plant material. Weight was obtained after drying the seagrasses and seaweeds at $60^{\circ} \mathrm{C}$ for $3 \mathrm{~d}$.

Expt 1: Effect of Thalassia testudinum density on Manicina areolata. Colonies of $M$. areolata from the naturally occurring population were transplanted into the 3 zones ( $\mathrm{H}, \mathrm{M}$, and $\mathrm{L}$ ). The colonies in the Zone $\mathrm{M}$, with a medium density of $T$. testudinum, functioned as a control. Eighteen numbered metal stakes were driven into the sand bottom in each zone in a northsouth-oriented row $1 \mathrm{~m}$ apart from each other (Fig. 1). One colony of $M$. areolata was placed $10 \mathrm{~cm}$ away from each side of the stakes (Fig. 2), following a northsouth orientation. Three size classes of $M$. areolata were transplanted to each experimental zone: juvenile ( $\leq 3.5 \mathrm{~cm}$ in length), small adults (SA, 3.6 to $6.5 \mathrm{~cm}$ in length), and large adults (LA, $>6.5 \mathrm{~cm}$ in length). A total of 36 colonies per size class (12 per experimental zone) were transplanted. Healthy colonies were selected for transplantation according to their color (light to dark brown) and absence of visible injuries, and by eliminating those with the presence of crab cavities (10\% of naturally occurring colonies). During handling, $M$. areolata was continuously maintained in seawater, using a floating rectangular metallic basket. The same precautions were utilized during the survival experiments with juveniles and recruits of $M$. areolata as described below.

A 2-color code was assigned to each numbered stake. Side (N/S) and position of each Manicina areolata was indicated by coloring its aboral portion with 
wax colors. Transplantation experiments were initiated on June 6, 1997. Measurements of displacement and survival of $M$. areolata colonies were obtained on June 9, 14, 20 and 28, July 11, and September 3, 1997. The displacement, or change from the original position, of the colonies of $M$. areolata was measured using a metric band, and the angle of movement (from the N-S oriented row) with a plastic protractor. After each measurement, displaced colonies were returned to their original position. The angle and displaced distance were calculated following Rees \& Sparks (1970). The percentage of displaced colonies in each zone was calculated as the proportion between the sum of the position changes by all the colonies within each size class and the total number of potential moving colonies during the experiment (for each size class: 12 colonies multiplied by 6 observation dates $=72$, except in Zone $\mathrm{L}$, where the numbers were low because of mortality of colonies; see below). The mean proportion of displaced colonies was compared for differences using 2-way ANOVAs. Descriptive statistical parameters for circular distributions, such as vector, mean angle of displacement and distribution range for each size class in each zone, were obtained. The Rayleigh test was applied to these data with $H_{0}=$ there is no mean population direction of movement (Zar 1984).

Zooxanthellae, chl a, and mitotic index: On September 3, 3 of the Manicina areolata colonies of each size class that had been transplanted on June 6 to the H, M, and L zones were collected, and each was maintained separately in 11 plastic containers with seawater. The plastic containers were placed into an insulated box containing seawater in order to eliminate the possibility of zooxanthellae expulsion caused by rapid changes in temperature (Gil-Turnes \& Corredor 1981). Eight hours after collection, live tissue was extracted from each colony following Johannes \& Wiebe (1970). The blastate was homogenized and the volume measured. Three aliquots of $10 \mathrm{ml}$ of blastate for each colony were separated for chl a determination, following Lorenzen \& Jeffrey (1978). The extractions were filtered through a Whatman 40 filter paper to eliminate skeletal residues (Carricart-Ganivet \& Beltrán-Torres 1993). A Spectronic ${ }^{\circledR} 1001+$ spectrophotometer was used and chl a concentrations were calculated according to the equations of Jeffrey \& Humphrey (1975).

For measurements of zooxanthellae density and mitotic index, $100 \mathrm{ml}$ of blastate in each sample was fixed by adding $4 \mathrm{ml}$ of formalin. To determine the density of zooxanthellae of each sample, 10 replicate cell counts were made using an hemocytometer after gentle homogenization of the fixed blastate (CarricartGanivet \& Beltrán-Torres 1993). To quantify the mitotic index, the fixed blastate of each sample was centrifuged $(5 \mathrm{ml}$ at $5000 \mathrm{rpm}[3920 \times g])$, the supernatant was eliminated, and the pellet was resuspended in $5 \mathrm{ml}$ of distilled water. Two replicate 1000 zooxanthellae counts were made using an hemocytometer to register the number of cells that were dividing (Wilkerson et al. 1983). The skeletal portion of each colony was thoroughly washed in running water, and its surface area later determined using the aluminum foil procedure

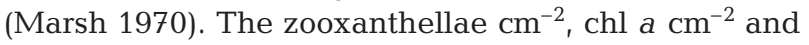
chl a zooxanthella ${ }^{-1}$ were calculated from these data.

Expt 2: Righting reaction of Manicina areolata. On June 6, 1997, another experimental setting was placed in Zone $M$, parallel to the ones used in the former experiment (Fig. 1). Here, 36 colonies of $M$. areolata (12 juveniles, 12 SA and 12 LA), all with their oral portion placed on the substrate, were positioned alongside 18 numbered metal stakes as in the previous experiment. The date that each colony returned to its normal position was recorded. The observation dates were June 8, 9, 14, 20 and 28 and July 11, by which time all the colonies had become righted. As a control, we used the $M$. areolata colonies placed in a normal position for Expt 1.

Expt 3: Importance of Neogoniolithon sp. to the survival of juvenile Manicina areolata. We tested the hypothesis that the branching architecture of the coralline algae Neogoniolithon sp. functioned as an 'anchor' for juveniles of $M$. areolata, thereby increasing their survival. To test this hypothesis, another experiment was set up within Zone M. On June 6, 1997, 12 juvenile colonies of $M$. areolata, each between 0.8 and $3.5 \mathrm{~cm}$ in length and each adhering to a branched coralline algae, were collected. Attached algae were removed from all colonies, and each colony was placed beside 6 stakes, in a $5 \mathrm{~m}$ long row as in previous experiments (Fig. 1). The control was the 12 juvenile colonies (with attached algae) of Expt 1. The survival of colonies was recorded on the same dates as Expt 1.

Expt 4: Importance of Neogoniolithon sp. for Manicina areolata recruits. Distribution and biomass of Neogoniolithon sp.: During a preliminary survey it was determined that the coralline algae on which juvenile colonies attached had a patchy distribution. To quantify patches, on June 9, 4 transects of $70 \times 2 \mathrm{~m}$ were placed parallel to the shoreline in Zones $\mathrm{H}, \mathrm{M}$, and L. All patches located along the transects were classified as small (0.2 to $1.0 \mathrm{~m}$ in diameter), and large (>1.0 $\mathrm{m}$ in diameter). Coralline algal biomass was measured from 2 haphazardly chosen patches, one small and one large, by collecting all specimens of this species in three $0.0625 \mathrm{~m}^{2}$ quadrats at each patch. In the laboratory, the samples were dried at $60^{\circ} \mathrm{C}$ for $3 \mathrm{~d}$. Total and individual weights of 10 specimens were obtained for each sample, using a Sartorius ${ }^{\circledR}$ PT600 balance. 
Survival of recruits of Manicina areolata: Once the patches of coralline algae were located, we found that recruits of $M$. areolata of millimeter size $(<10 \mathrm{~mm})$ were relatively easy to see with the unaided eye. We prepared an additional experiment within Zone $\mathrm{M}$ (Fig. 1) in order to measure the survival of recruits, with and without attached algae. This test was important because the recruits of $M$. areolata were not represented in Expt 3 (in that experiment, only 1 colony measured less than $10 \mathrm{~mm}$ in length).

On June 14, 1997, 40 recruits without visible signs of damage were collected from the coralline algae patches and placed within a radius of $5 \mathrm{~cm}$ from 4 metal stakes. Twenty recruits with attached algae were placed at 1 pair of stakes, while the other 20 recruits, without algae, were placed at the other 2 stakes. The separation of recruits and algae was accomplished by carefully breaking only the algae, never the coral, and using a pincer when necessary to break remaining parts of the algae. The number of live recruits was counted on June 28. Our observations of the movement of colonies suggested that it was possible that recruits were lost due to displacement, not mortality, so on June 28 we repeated the experiment, but now using enclosures. Twenty-four recruits with algae and 20 recruits without algae were placed inside an enclosure $20 \times 20 \mathrm{~cm}, 5 \mathrm{~cm}$ in height, made with 4 stakes and a fence of plastic window screen. For this trial, the percentage of surviving recruits was determined on July 11. The same experiment was repeated starting on June 2, 1998, placing 24 recruits with algae and 23 without algae in 2 enclosures, and ending on June 30, 1998. The length of all transplanted recruits used in the preceding 3 experiments was 2 to $8 \mathrm{~mm}$.

\section{RESULTS}

\section{Distribution, density, and size of Manicina areolata and Thalassia testudinum}

The mean total density and cover values of Manicina areolata (juveniles + adults), and the mean density and height values of the seagrasses Thalassia testudinum and Syringodium filiforme on all transects are given in Table 1.

The distribution of juvenile colonies of Manicina areolata was slightly more restricted (in Transects 2 to 6) than adult colonies (in Transects 2 to 7 ). The spatial distribution of all colonies (juveniles + adults) was aggregated on Transects 2, 4, and 5 (Fig. 4). However, only on Transect 4 did the clump pattern present a high definition and intensity, with a mean distance of $16 \mathrm{~m}$ between groups (twice the size of the block associated with the peak; Ludwig \& Reynolds 1988). A

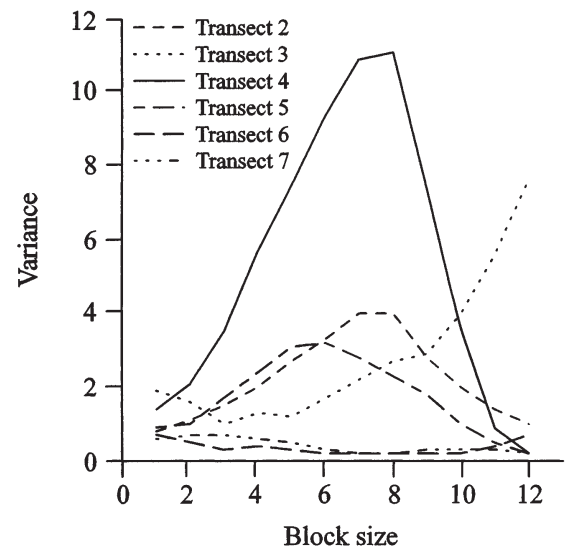

Fig. 4. Manicina areolata. Spatial distribution pattern within 6 transects at Xahuayxol, according to the local quadratic variance of 2 terms method. $M$. areolata colonies were not found on Transects 1, 8, and 9 (see Table 1)

random distribution was found for the colonies at Transects 6 and 7 .

The correlation coefficients and linear regressions indicated a significant negative relationship between the density of Thalassia testudinum and the density and cover of Manicina areolata juveniles and adult colonies (Fig. 5). On the other hand, the size of T. testudinum and the density and size of Syringodium filiforme were not significantly related $(p>0.05)$ to the population variables of $M$. areolata.

A significant positive relationship $(\mathrm{p}<0.01)$ existed between the density of adult Manicina areolata colonies and the density and cover of juvenile colonies $\left(r^{2}=0.67\right.$ and $r^{2}=0.64$, respectively). Similarly, adult cover exhibited a positive relationship $(p<0.05)$ with the density and cover of juveniles $\left(\mathrm{r}^{2}=0.52\right.$ and $r^{2}=0.45$, respectively).

\section{Characterization of the experimental zones with different Thalassia testudinum density}

\section{Sediment}

The results of the 1-way ANOVA, HSD Tukey's test indicated that Zone $\mathrm{M}$ contained a significantly higher percentage $(p<0.001)$ of coarse sand $(24.0 \%)$ than Zones H $(7.3 \%)$ and L $(9.0 \%)$. Zone L had a significantly higher percentage $(\mathrm{p}<0.001)$ of medium sand $(23.7 \%)$ than Zones H $(9.2 \%)$ and M $(11.7 \%)$. The sediment in Zone $\mathrm{H}$ was composed of more $(\mathrm{p}<0.001)$ fine sand $(83.4 \%)$ than Zones $M(63.5 \%)$ and L $(66.0 \%)$. The percentage of very fine sand in Zone $\mathrm{H}(0.13 \%)$ was significantly lower $(\mathrm{p}<0.01)$ only in comparison with Zone L (1.27\%). 


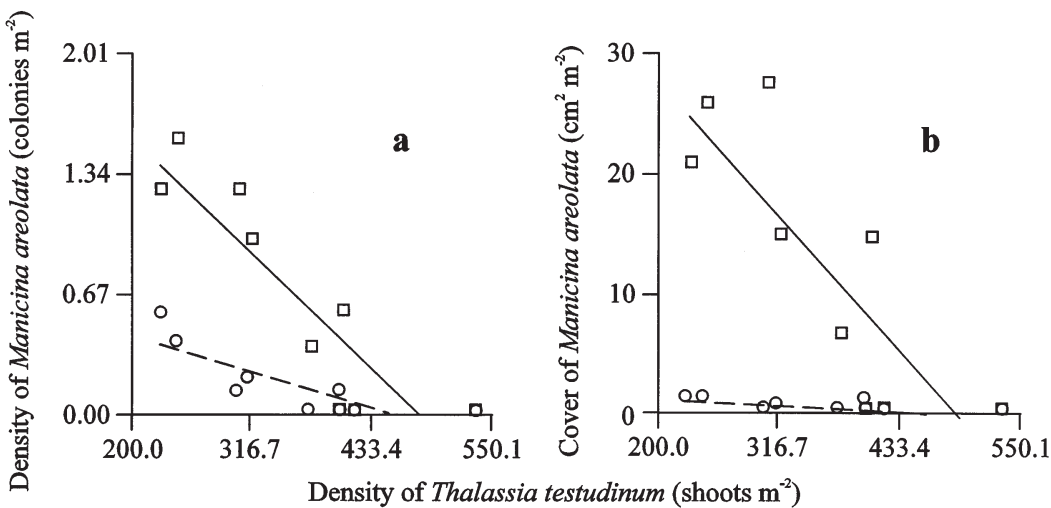

Fig. 5. Relationships between density of Thalassia testudinum and (a) density and (b) cover of juveniles (o) and adults ( $\mathrm{a}$ ) of Manicina areolata. Regression lines are: $y=0.77-0.002 x\left(r^{2}=0.69, p=0.006\right), y=2.65-0.006 x\left(r^{2}=0.79\right.$, $\mathrm{p}=0.001), y=2.32-0.005 x\left(\mathrm{r}^{2}=0.61, \mathrm{p}=0.01\right)$, and $y=46.27-0.094 x\left(\mathrm{r}^{2}=0.69\right.$, $\mathrm{p}=0.006)$, respectively

Irradiance and temperature

Mean bottom irradiance in Zone $\mathrm{H}$ was $138 \mu \mathrm{mol}$ $\mathrm{m}^{-2} \mathrm{~s}^{-1}$, in Zone M $657 \mu \mathrm{mol} \mathrm{m} \mathrm{m}^{-2} \mathrm{~s}^{-1}$, and in Zone $\mathrm{L}$ $637 \mu \mathrm{mol} \mathrm{m} \mathrm{m}^{-2} \mathrm{~s}^{-1}$. The temperature was similar in all 3 zones, between 28.5 and $28.7^{\circ} \mathrm{C}$.

\section{Plant biomass}

The most important plant component in the 3 zones was the seagrass Thalassia testudinum, with a biomass of $368 \mathrm{~g} \mathrm{~m}^{-2}$ in Zone $\mathrm{H}, 99 \mathrm{~g} \mathrm{~m}^{-2}$ in Zone M, and $24 \mathrm{~g}$ $\mathrm{m}^{-2}$ in Zone L. The seagrass Syringodium filiforme was second in importance, but it was present only in Zones $\mathrm{H}$ and $\mathrm{M}$, with 280 and $4.8 \mathrm{~g} \mathrm{~m}^{-2}$, respectively. Other plant elements were only found in Zone M: Halimeda incrasata (Ellis) Lamouroux (11.2 $\left.\mathrm{g} \mathrm{m}^{-2}\right)$, Penicillus lamourouxii Decaisne $\left(3.2 \mathrm{~g} \mathrm{~m}^{-2}\right)$, Udotea flavellum (Ellis \& Solander) Lamouroux $\left(3.2 \mathrm{~g} \mathrm{~m}^{-2}\right)$, and Neogoniolithon $\mathrm{sp} .\left(0.5 \mathrm{~g} \mathrm{~m}^{-2}\right)$.

\section{Expt 1: Effect of Thalassia testudinum density on Manicina areolata}

\section{Mortality and displacement}

Zone L, with low densities of Thalassia testudinum, was different from the other 2 zones because mortality and loss of coral colonies only occurred there. By July $11,1997,83 \%$ (10) of the juvenile colonies in Zone L had been registered as dead or missing; the other 2 colonies died between that date and September 3, 1997. By September 3, 50\% of the SA and 33\% of the LA of Manicina areolata were also recorded as dead and/or lost. The great majority of dead colonies had clear bite marks on most of their surface area (Fig. 6a), caused, possibly, by coralivorous fishes. Another cause of coral mortality was asphyxia, due to sediment burial (Fig. 6b).

The mean distance of displacement, in $\mathrm{cm}$, for juvenile, SA, and LA of Manicina areolata colonies was 14, 5 and 0 within Zone $\mathrm{H}, 12,10$ and 35 within Zone L, and 15, 14 and 0 within Zone $\mathrm{M}$, respectively. There was no significant difference in displacement between size classes in each zone, nor among zones (1-way ANOVA, $\mathrm{p}>0.53$, in all cases). The proportion of displaced colonies was very low (Fig. 7). Within Zone $\mathrm{H}$, there was less displacement (2\%) than in Zones M $(6 \%)$ and L (8\%) but it was not significantly different (2-way ANOVA, $\mathrm{p}>0.05,1-\alpha=0.90)$. However, in each zone, juveniles had a greater percentage of displaced colonies than SA
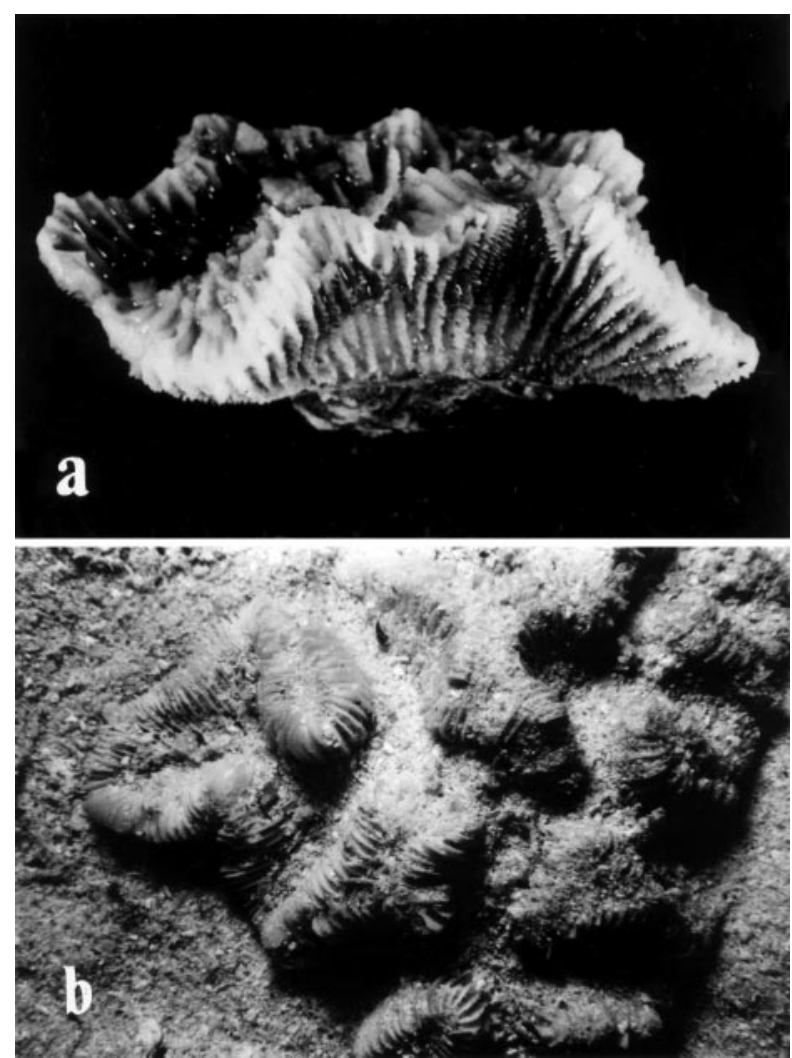

Fig. 6. Manicina areolata. (a) Skeleton of a juvenile found dead in the zone of low density of Thalassia testudinum (35 shoots $\left.\mathrm{m}^{-2}\right)$; note the bite marks on its edges $(\times 0.4)$. (b) In situ buried adult of Manicina areolata in the same zone $(\times 0.8)$. Photos by H. Bahena-Basave 


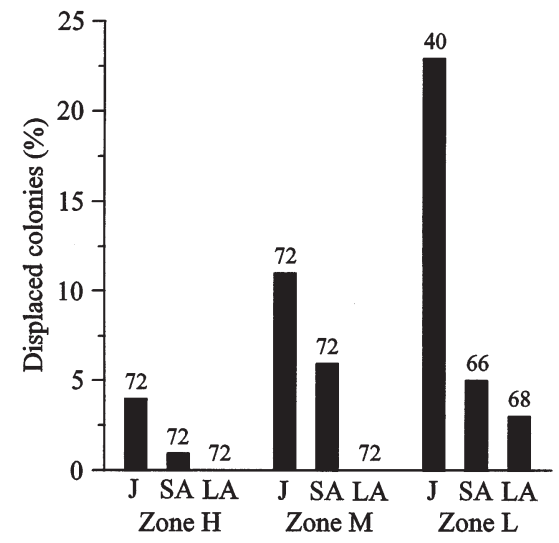

Fig. 7. Manicina areolata. Percentage of displacement of juveniles ( $\mathrm{J}, \leq 3.5 \mathrm{~cm}$ in length), small adults (SA, 3.6 to $6.4 \mathrm{~cm}$ in length) and large adults (LA, $\geq 6.4 \mathrm{~cm}$ in length) in the 3 experimental zones of Thalassia testudinum density $(\mathrm{H}=$ 542 shoots $\mathrm{m}^{-2}, \mathrm{M}=239$ shoots $\mathrm{m}^{-2}, \mathrm{~L}=35$ shoots $\mathrm{m}^{-2}$ ). Numbers above bars indicate the number of observations in each case. The number of observations in Zone L was lower due to the mortality that occurred within this zone (see text for details)

and LA (2-way ANOVA, $\mathrm{p}<0.05,1-\alpha=0.90$; LSD test, $\mathrm{p}<0.05$ ) (Fig. 7). There was no mean direction of displacement for the colonies according to Rayleigh's test ( $p<0.1$, in all cases). Thus, displacement of colonies was random.

\section{Zooxanthellae, chl $a$, and mitotic index}

The mean values of zooxanthellae $\mathrm{cm}^{-2}$, chl a zooxanthella $^{-1}$, chl a $\mathrm{cm}^{-2}$, and the mitotic index (Table 2) did not differ significantly between size classes of Manicina areolata in each experimental zone (1-way ANOVAs, $p>0.05$, in all cases). Based on these results, only zones were considered in subsequent statistical analysis. The mean number of zooxanthellae $\mathrm{cm}^{-2}$ of M. areolata from Zone $H\left(2.775 \times 10^{6}\right)$ was significantly lower (Tukey's HSD test, p < 0.001) than those from Zones L $\left(4.736 \times 10^{6}\right)$ and $M\left(3.486 \times 10^{6}\right)$, but the latter were not statistically different. Mean values of chl a zooxanthella ${ }^{-1}$, chl $\mathrm{a} \mathrm{cm}^{-2}$, and mitotic index were not significantly different among the 3 experimental zones ( $p>0.05$, in all cases).

\section{Expt 2: Righting reaction of Manicina areolata}

Righting reaction time increased with size/weight of the colonies, from $8 \mathrm{~d}$ for the juveniles to $14 \mathrm{~d}$ for SA to $35 \mathrm{~d}$ for LA. Control colonies, which were placed upright, exhibited a very low percentage of overturned colonies for all 3 size classes (Table 3 ).

\section{Expt 3: Importance of Neogoniolithon sp. to the survival of juvenile Manicina areolata}

We did not record mortality for juvenile colonies of Manicina areolata to which Neogoniolithon sp. was not available as a substrate.

\section{Expt 4: Importance of Neogoniolithon sp. for Manicina areolata recruits}

Distribution and biomass of Neogoniolithon sp.

Patches of Neogoniolithon sp. were found only within Zone M, with a larger number of small (16) than large patches (5). In the small patches, the mean biomasses per area (5889.6 $\mathrm{g} \mathrm{dw}$ [dry weight] $\mathrm{m}^{-2}$ ) and per individual (3.2 $\mathrm{g} \mathrm{dw}$ ) were greater than the corresponding mean values for the large patches $\left(2937.6 \mathrm{~g} \mathrm{dw} \mathrm{m}^{-2}\right.$ and $1.2 \mathrm{~g} \mathrm{dw}$, respectively).

Survival of juveniles and recruits of Manicina areolata

In the experiment without an enclosure, where $\mathrm{Neo}$ goniolithon sp. was manually removed from Manicina areolata recruits, only $25 \%$ of the recruits survived, in comparison to $85 \%$ for recruits with algae attached. In the similar experiment with an enclosure, the survival

Table 2. Average zooxanthellae density $\left(\mathrm{cm}^{-2}\right)$, chl a zooxanthella ${ }^{-1}$, chl a $\mathrm{cm}^{-2}$, and the mitotic index (\%) per size class of Manicina areolata, in the 3 experimental zones. The measurements of juvenile colonies in Zone L are not given due to their mortality (see text for details). Acronyms as in Fig. 7

\begin{tabular}{|c|c|c|c|c|c|c|c|c|c|c|c|c|}
\hline \multirow[t]{2}{*}{ Zone } & \multicolumn{3}{|c|}{$\begin{array}{l}\text { Zooxanthellae } \mathrm{cm}^{-2} \\
\qquad\left(\times 10^{6}\right)\end{array}$} & \multicolumn{3}{|c|}{$\begin{array}{c}\mu g \text { chl a zooxanthella }{ }^{-1} \\
\left(\times 10^{-6}\right)\end{array}$} & \multicolumn{3}{|c|}{$\mu \mathrm{g}$ chl $a \mathrm{~cm}^{-2}$} & \multicolumn{3}{|c|}{$\begin{array}{l}\text { Mitotic index } \\
(\%)\end{array}$} \\
\hline & $\mathrm{J}$ & SA & LA & $\mathrm{J}$ & $\mathrm{SA}$ & LA & $\mathrm{J}$ & SA & LA & $\mathrm{J}$ & SA & LA \\
\hline $\mathrm{H}$ & 2.93 & 3.30 & 2.09 & 2.26 & 2.34 & 2.98 & 6.44 & 7.65 & 9.08 & 8.8 & 8.4 & 6.6 \\
\hline M & 2.96 & 3.77 & 3.73 & 1.63 & 2.42 & 2.21 & 5.04 & 9.08 & 8.20 & 10.7 & 8.9 & 10.3 \\
\hline $\mathrm{L}$ & - & 4.52 & 4.95 & - & 1.68 & 1.80 & - & 7.59 & 8.41 & - & 9.8 & 9.7 \\
\hline
\end{tabular}


Table 3. Manicina areolata. Percentage (\%) of righting reaction of 12 colonies per size class for each observation date and number of days elapsed since the beginning of the experiment. Control refers to percentage of overturned colonies per size class in Zone $\mathrm{M}$ at the end of the experiment (see text for explanation). Acronyms as in Fig. 7

\begin{tabular}{|lcrrr|}
\hline \multirow{2}{*}{$\begin{array}{l}\text { Date of } \\
\text { observation }\end{array}$} & $\begin{array}{c}\text { Number of } \\
\text { elapsed days }\end{array}$ & \multicolumn{4}{c|}{ Percentage of righting } \\
& J & SA & LA \\
\hline Jun 6 & 0 & & & \\
Jun 8 & 2 & 33 & 42 & 0 \\
Jun 9 & 3 & 58 & 58 & 17 \\
Jun 14 & 8 & 100 & 92 & 75 \\
Jun 20 & 14 & & 100 & 92 \\
Jun 28 & 22 & & & 92 \\
Jul 11 & 35 & & & 100 \\
Control & & 1.2 & 2.4 & 3.6 \\
Sep 3 & 89 & & & \\
\hline
\end{tabular}

of $M$. areolata recruits without algae was $40 \%$, versus $75 \%$ survival of recruits with algae attached. In the replication of the latter experiment, the survival of recruits without and with coralline algae attached was 58 and $100 \%$, respectively. Considering that there was no significant difference in survival within experiments with and without the enclosure $(t$-test $=-0.59$, $\mathrm{p}<0.58)$, the results of the 3 experiments were grouped. Then, the survival was significantly greater ( $t$-test $=3.77, \mathrm{p}<0.03$ ) for recruits of $M$. areolata with Neogoniolithon sp. attached (87\%) than for those without algae $(41 \%)$.

\section{DISCUSSION}

\section{Importance of Thalassia testudinum and Neogoniolithon sp. to the distribution of Manicina areolata}

The mean value (0.8) and total range (0.4 to 1.9$)$ of juvenile plus adult Manicina areolata colonies $\mathrm{m}^{-2}$ found in this study (Table 1) are similar to (Chiappone \& Sullivan 1991) or greater than (Johnson 1992b, Chiappone \& Sullivan 1994) other density values reported in the literature. However, the maximum density of $M$. areolata in the Caribbean Sea can be up to 12 colonies $\mathrm{m}^{-2}$ and under exceptional circumstances up to 70 colonies $\mathrm{m}^{-2}$ (Johnson 1988, 1992a,b). The cover values of $M$. areolata found here $\left(7.0\right.$ to $27.5 \mathrm{~cm}^{2} \mathrm{~m}^{-2}$; Table 1) are greater than the values reported by Chiappone \& Sullivan (1994) in the Florida Keys $\left(0.1 \mathrm{~cm}^{2} \mathrm{~m}^{-2}\right)$ and by Chiappone \& Sullivan (1991) in the Bahamas $(0.0$ to $8.9 \mathrm{~cm}^{2} \mathrm{~m}^{-2}$ ).

The population of Manicina areolata, a brooding coral (Boschma 1929, Johnson 1992b) from Xahuayxol, was comprised mainly of adult colonies $(>3.5 \mathrm{~cm}$ in length, Table 1). As with other brooding scleractinian species (Chiappone \& Sullivan 1996), we found a strong correlation between the density and cover of adult colonies and the density and cover of juvenile colonies. This probably is indicative of a population in which the supply of larvae depends on local adult colonies, meaning that each local colony is relatively isolated from other populations. These correlations can also be a characteristic of life histories of massive brooding species of relatively small size inhabiting unstable environments, as Soong (1993) reported for several species of coral from the Indo-Pacific and the Atlantic Ocean. On the other hand, we do not know of any other study reporting the aggregated distribution of $M$. areolata such as occurs at Xahuayxol. Our data indicate that the distance between patches was between 10 and $16 \mathrm{~m}$.

Thalassia testudinum, Syringodium filiforme, and Halodule wrightii, found at Xahuayxol, were also reported from the west coast of Florida and the Caribbean portion of the Yucatán Peninsula (Zieman \& Zieman 1989, Espinoza-Avalos 1996). The density and height values of $T$. testudinum found at Xahuayxol are within the ranges previously recorded by other authors for the Gulf of Mexico, the Mexican Caribbean, and Florida (De la Lanza et al. 1991, Gallegos et al. 1993, Lapointe et al. 1994). However, the mean density of $S$. filiforme in this seagrass meadow is 24 and 17 times lower than in reports from the Bahamas (Short et al. 1985) and northern Quintana Roo (Gallegos et al. 1994), respectively, and its mean height at our study site is 1.5 times lower than that recorded by Short et al. (1985) in the Bahamas. These differences could be because $S$. filiforme is intermixed with $T$. testudinum at Xahuayxol, whereas at the other 2 sites it grows alone.

Manicina areolata was not normally present at high and low densities of Thalassia testudinum (Table 1), and at medium densities exhibited an inverse relationship with the density of seagrass (Fig. 5). It has been recognized that the biomass and cover of marine plant communities influence the distribution and ecological links of benthic fauna (Stoner 1980, Fisk 1983). However, the highly significant relationship found at Xahuayxol between $M$. areolata and $T$. testudinum did not explain the distribution of the former species in Zone $M$, which is better attributed to the distribution of the coralline algae Neogoniolithon sp., as discussed below.

\section{Effect of Thalassia testudinum density on Manicina areolata}

The mobility of some scleractinian corals represents an important adaptive feature that provides the oppor- 
tunity for them to colonize different environments (Glynn 1974, Hoeksema 1988, Lewis 1989, ChadwickFurman \& Loya 1992). However, a very low displacement was registered for the 3 size classes of the freeliving coral Manicina areolata within the 3 experimental zones of this study. Free-living species can be displaced to environments that may have fatal consequences (Hoeksema 1988). Such a possibility was evident in this study for colonies transplanted to Zone L, where all juvenile and several adult coral colonies died because of predation and siltation (Fig. 6). The sediment of this zone not only contained $90 \%$ medium and fine sand, but also was not compacted (pers. obs.). Both factors probably facilitate resuspension of the sediment and, consequently, burial and death of colonies (see Yonge 1936). A decrease in movement has been observed in unattached corals as they increase in size (Glynn 1974, Hoeksema 1988, Chadwick-Furman \& Loya 1992). The same was found for $M$. areolata transplanted into 3 experimental zones, although the percentage of displaced colonies in our study was very low (Fig. 7).

The specimens of Manicina areolata transplanted into Zone $\mathrm{H}$ suffered stress caused by environmental factors; this was measured as a significant decrease in the number of zooxanthellae $\mathrm{cm}^{-2}$. It is known that under stress hermatypic corals use digestion and/or expulsion mechanisms in order to regulate their number of zooxanthellae (Titlyanov et al. 1996). The quantity and quality of light is one factor causing changes in the density of zooxanthellae, photosynthetic pigments, and mitotic index of scleractinian corals (Dustan 1979, Titlyanov 1981, Wilkerson et al. 1983, Kinsie et al. 1984). Nonetheless, the chl a zooxanthella ${ }^{-1}$, chl a $\mathrm{cm}^{-2}$, and mitotic index of transplants did not change compared to the control colonies located in Zone M (Table 2). In our study, the irradiance in Zone $\mathrm{H}$ was on average 4.7 times lower than in the other 2 zones. We think that the low light level found in Zone H caused the stress, and, consequently, a lower number of zooxanthellae $\mathrm{cm}^{-2}$.

\section{Righting reaction of Manicina areolata}

The disproportionately large surface area in relation to size (volume) found in the free-living form of Manicina areolata has been interpreted as an adaptive specialization to colonize sandy bottoms, and for righting ability if overturned by waves and sea currents (Goreau \& Goreau 1960). Nonetheless, quantitative evaluations of these behaviors have not been studied sufficiently for this coral species.

All Manicina areolata of the 3 size classes returned to their normal position after $35 \mathrm{~d}$, before the end of the experiment. The juveniles reached $100 \%$ righted before adult colonies (Table 3). This is similar to the findings of Johnson (1988), who mentioned that the righting reaction was limited by the size of the colony. The percentage of overturned control colonies was insignificant for the 3 size classes (Table 3), suggesting that righting ability is actively controlled by $M$. areolata (Goreau \& Goreau 1960). The process, then, is not dictated by stochastic factors (i.e. sea currents, bioturbation), as was proposed by Fabricius (1964) for $M$. areolata and by Chadwick-Furman \& Loya (1992) for Indo-Pacific fungiids. The low displacement distance for the 3 size classes registered within the $89 \mathrm{~d}$ of the experiment also confirms that the righting reaction, which is relatively rapid, is controlled by $M$. areolata and, in addition, did not play an important role in its displacement.

\section{Importance of Neogoniolithon sp. to the survival of Manicina areolata}

Differential larval settlement can be an influencing variable for recruitment, particularly on hard substrates (Pawlik 1992). In our study, $92 \%$ of the Manicina areolata recruits were found attached to Neogoniolithon sp. (Fig. 3). Pawlik (1992) stated that the recruitment of marine benthic invertebrates shows variable spatial and temporal patterns, attributable to numerous factors occurring before, during or after settlement. Although recruits and juvenile colonies of $M$. areolata were attached to Neogoniolithon sp., it was demonstrated that the algae was not important for the survival of the juvenile stage. However, the recruits suffered significant mortality when separated from the algae, placing importance on the arborescent structure of the algae, which provides the possibility of escaping asphyxia for recruits living in sandy environments. It has been demonstrated that coral planula avoid substrates with high sedimentation rates (Hodgson 1990). The above data and this information demonstrate that Neogoniolithon sp. is only important for the early stages of $M$. areolata. All adult colonies observed during this study lacked attached algae, implying that at a specific weight the growing coral eventually separates from the fragile algae, as noted previously for $M$. areolata attached to shells and other corals (Goreau \& Goreau 1960). It is important to note that while decalcifying recruits of $M$. areolata attached to Neogoniolithon sp. for identification of the algae the organisms separated easily, without cellular modifications on the contact site, indicating that the settlement of the coral did not physically injure the algal tissue.

It is thought that the patchy spatial distribution of coralline algae and the preferential larval settlement on live substrates causes an aggregated distribution 
pattern of adults (Carlon \& Olson 1993). In our study, the patchy distribution of Neogoniolithon sp., the recruitment of Manicina areolata associated to those algae patches, and the relatively patchy distribution of adult $M$. areolata colonies support that notion.

In summary, the distribution of Manicina areolata was restricted to densities of Thalassia testudinum between 231 and 407 shoots $\mathrm{m}^{-2}$. At these densities, a significant relationship was found between the density of $T$. testudinum and the density and cover of $M$. areolata. However, the density of T. testudinum does not explain the distribution of $M$. areolata. The coral distribution is explained by the distribution of Neogoniolithon sp., an arborescent alga here used preferentially by $M$. areolata for recruitment. The strong Neogoniolithon sp.-M. areolata relationship, and the distribution of the algae, gives adaptive and ecological advantages to $M$. areolata. Neogoniolithon sp. offers a recruitment substrate that increases the survival of $M$. areolata by helping to avoid siltation. On the other hand, the distribution of Neogoniolithon sp. may prevent $M$. areolata from settling in zones where the corals would be subject to ecological stress (i.e. lowirradiance regimes) and death by predation and/or siltation. These findings show that even though shallow reef coral zones are among the most studied communities, not all ecological relationships have been discovered.

Acknowledgements. We thank R. Herrera-Pavón and C. Nahuat-Lara for their help in field work, A. U. Beltrán-Torres for measuring the mitotic index, and the number of zooxanthellae, and for assistance with determinations of chl $a$, and $\mathrm{H}$. Bahena-Basave for providing the photographs. Special thanks to Scott Monks for correcting the English, and for his valuable comments on the first draft of the manuscript. The observations of Judy Lang and 3 anonymous referees substantially improved the manuscript. This study was made possible with the financial support of CONACYT Project 4120PN9607.

\section{LITERATURE CITED}

Babcock R, Mundy C (1996) Coral recruitment: consequences of settlement choice for early growth and survivorship in 2 scleractinians. J Exp Mar Biol Ecol 206:179-201

Bak RPM, Engel MS (1979) Distribution, abundance and survival of juvenile hermatypic corals (Scleractinia) and the importance of life history strategies in the parent coral community. Mar Biol 54:341-352

Boschma H (1929) On the postlarval development of the coral Maeandra areolata (L.) Pap Tortugas Lab 26:129-147

Brown BE (1988) Assessing environmental impacts on coral reefs. Proc 6th Int Coral Reef Symp, Australia 1:71-80

Brown BE, Howard LS (1985) Assessing the effects of 'stress' on reef corals. Adv Mar Biol 22:1-63

Carlon DV, Olson RR (1993) Larval dispersal distance as an explanation for adult spatial pattern in 2 Caribbean reef corals. J Exp Mar Biol Ecol 173:247-263
Carricart-Ganivet JP, Beltrán-Torres AU (1993) Zooxanthellae and chlorophyll a responses in the scleractinian coral Montastrea cavernosa at Triángulos-W Reef, Campeche Bank, Mexico. Rev Biol Trop 41:491-494

Chadwick-Furman N, Loya Y (1992) Migration, habitat use, and competition among mobile corals (Scleractinia: Fungiidae) in the Gulf of Eilat, Red Sea. Mar Biol 114:617-623

Chiappone M, Sullivan KM (1991) A comparison of line transect versus linear percentage sampling for evaluating stony coral (Scleractinia and Milleporina) community similarity and area coverage on reefs of the central Bahamas. Coral Reefs 10:139-154

Chiappone M, Sullivan KM (1994) Patterns of coral abundance defining nearshore hardbottom communities of the Florida Keys. Fla Scient 57:108-125

Chiappone M, Sullivan KM (1996) Distribution, abundance and species composition of juvenile scleractinian corals in the Florida Reef Tract. Bull Mar Sci 58(2):555-569

De la Lanza G, Rodríguez-Medina M, Soto LA (1991) Análisis ecológico de los productores primarios en la laguna de Términos, Campeche, Mexico. Universidad y Ciencia 8(15): $15-25$

Dustan P (1979) Distribution of zooxanthellae and photosynthetic chloroplast pigments of the reef-building coral Montastrea annularis (Ellis and Solander) in relation to depth on a West Indian coral reef. Bull Mar Sci 29:79-91

Espinoza-Avalos J (1996) Distribution of seagrasses in the Yucatan Peninsula, Mexico. Bull Mar Sci 59:449-454

Fabricius F (1964) Aktive Lage- und Ortsveränderung bei der Koloniekoralle Manicina areolata und ihre palaookologische Bedeutung. Senck Leth 45:299-323

Fisk DA (1983) Free-living corals: distributions according to plant cover, sediments, hydrodynamics, depth and biological factors. Mar Biol 74:287-294

Folk RL (1969) Petrología de las rocas sedimentarias. Instituto Geología, UNAM, Mexico City

Gallegos ME, Merino M, Marbá N, Duarte CM (1993) Biomass and dynamics of Thalassia testudinum in the Mexican Caribbean: elucidating rhizome growth. Mar Ecol Prog Ser 95:185-192

Gallegos ME, Merino M, Rodríguez A, Marbá N, Duarte CM (1994) Growth patterns and demography of pioneer Caribbean seagrass Halodule wrightii and Syringodium filiforme. Mar Ecol Prog Ser 109:99-104

Gil-Turnes S, Corredor J (1981) Studies of photosynthetic pigments of zooxanthellae in Caribbean hermatypic corals. Proc 4th Int Coral Reef Symp, Manila 2:51-54

Glynn PW (1974) Rolling stones among the Scleractinia: mobile coralliths in the Gulf of Panama. Proc 2nd Int Coral Reef Symp, Brisbane 2:183-198

Goreau TF, Goreau NI (1960) The physiology of skeleton formation in corals. III. Calcification rate as a function of colony weight and total nitrogen content in the reef coral Manicina areolata (Linnaeus). Biol Bull 118:419-429

Grigg RW, Dollar SJ (1990) Natural and anthropogenic disturbance on coral reefs. In: Dubinsky Z (ed) Ecosystems of the world. 25. Coral reefs, Elsevier Science Publishers BV, Amsterdam, p 439-452

Hadfield MG (1986) Settlement and recruitment of marine invertebrates: a perspective and some proposals. Bull Mar Sci 39:418-425

Hodgson G (1990) Sediment and the settlement of larvae of the reef coral Pocillopora damicornis. Coral Reefs 9:41-43

Hoeksema BW (1988) Mobility of free-living fungiid corals (Scleractinia), a dispersion mechanism and survival strategy in dynamic reef habitats. Proc 6th Int Coral Reef Symp, Australia 2:715-720 
Jeffrey SW, Humphrey GF (1975) New spectrophotometric equations for determining chlorophyll $a, b, c_{1}$ and $c_{2}$ in higher plants, algae and natural phytoplankton. Biochem Physiol Pflanz 167:191-194

Johannes RE, Wiebe WJ (1970) Method for determination of coral tissue biomass and composition. Limnol Oceanogr 15:822-824

Johnson KG (1988) Size, meander pattern, and behavior in the Caribbean free-living meandroid coral Manicina areolata (Linnaeus). Proc 6th Int Coral Reef Symp, Australia 3: 403-408

Johnson KG (1992a) Population dynamics of a free-living coral: recruitment, growth and survivorship of Manicina areolata (Linnaeus) on the Caribbean coast of Panama. J Exp Mar Biol Ecol 164:171-191

Johnson KG (1992b) Synchronous planulation of Manicina areolata (Scleractinia) with lunar periodicity. Mar Ecol Prog Ser 87:265-273

Johnson KG, Budd AF, Stemann TA (1995) Extinction selectivity and ecology of Neogene Caribbean reef corals. Paleobiol 21:52-73

Jones RJ (1997) Zooxanthellae loss as a bioassay for assessing stress in corals. Mar Ecol Prog Ser 149:163-171

Kato T, Kumanireng AS, Ichinose I, Kitahara Y, Kakinuma Y, Nishihira M, Kato M (1975) Active components of Sargassum tortile affecting the settlement of swimming larvae of Coryne uchidai. Experientia 31:433-434

Kinzie RA III, Jokiel PL, York R (1984) Effects of light of altered spectral composition on coral zooxanthellae associations and zooxanthellae in vitro. Mar Biol 78:239-248

Lapointe BE, Tomasko DA, Matzie WR (1994) Eutrophication and trophic state classification of seagrass communities in the Florida Keys. Bull Mar Sci 54:696-717

Lewis JB (1989) Spherical growth in the Caribbean coral Siderastrea radians (Pallas) and its survival in disturbed habitats. Coral Reefs 7:161-167

Lorenzen CJ, Jeffrey SW (1978) Determination of clorophyll in seawater. UNESCO Tech Pap Mar Sci 35:1-20

Ludwig JA, Reynolds JF (1988) Statistical ecology. A primer on methods and computing. John Wiley \& Sons, New York

Marsh JA (1970) Primary productivity of reef building calcareous red algae. Ecology 51:255-263

Mattia CM (1997) A non-destructive spectrophotographic method of assessing relative changes in coral health utilizing induced fluorescence. Chesapeake Biological Laboratory, Solomons, MD (accessed: January 1999); available at http://cbl.cees.edu/ mattia/SMProject/

Morse ANC (1992) Role of algae in the recruitment of marine invertebrate larvae. In: John, DM, Hawkins SJ, Price JH (eds) Plant-animal interactions in the marine benthos. Systematics Association Spec Vol 46. Clarendon Press, Oxford, p 385-403

Morse ANC, Morse DE (1996) Flypapers for coral and other planktonic larvae. BioScience 46:254-262

Editorial responsibility: Rolf Bak (Contributing Editor), Den Burg, Texel, The Netherlands
Pawlik JR (1989) Larvae of the sea hare Aplysia californica settle and metamorphose on an assortment of macroalgal species. Mar Ecol Prog Ser 51:195-199

Pawlik JR (1992) Chemical ecology of the settlement of benthic marine invertebrates. Oceanogr Mar Biol Annu Rev 30:273-335

Peters EC, Meyers PA, Yevich PP, Blake NJ (1981) Bioaccumulation and histopathological effects of oil on a stony coral. Mar Pollut Bull 12(10):333-339

Rees PK, Sparks FW (1970) Álgebra y trigonometría. McGraw-Hill, Mexico City

Short FT, Davis MW, Gibson RA, Zimmermann CF (1985) Evidence for phosphorus limitation in carbonate sediments of the seagrass Syringodium filiforme. Estuar Coast Shelf Sci 20:419-430

Soong K (1993) Colony size as a species character in massive reef corals. Coral Reefs 12:77-83

Stoner AW (1980) The role of seagrass biomass in the organization of benthic macrofaunal assemblages. Bull Mar Sci 30:537-551

Switzer-Dunlap M (1978) Larval biology and metamorphosis of aplysiid gastropods. In: Chia FS, Rice ME (eds) Settlement and metamorphosis of marine invertebrate larvae. Elsevier, New York, p 197-206

Taylor WR (1960) Marine algae of the eastern tropical and subtropical coasts of the Americas. University of Michigan Press, Ann Arbor

Titlyanov EA (1981) Adaptation of reef-building corals to low light intensity. Proc 4th Int Coral Reef Symp, Manila 2:39-43

Titlyanov EA, Titlyanov TV, Leletkin VA, Tsukahara J, van Woesik R, Yamazato K (1996) Degradation of zooxanthellae and regulation of their density in hermatypic corals. Mar Ecol Prog Ser 139:167-178

Trapido-Rosenthal HG, Morse DE (1986) Availability of chemosensory receptors is down-regulated by habituation of larvae to a morphogenetic signal. Proc Natl Acad Sci USA 83:7658-7662

Vargas-Hernández JM (1991) Análisis granulométrico de sedimentos. Versión 1.0. Museo de Zoología, Facultad de Biología, Univ Veracruzana Xalapa, Mexico

Wilkerson FP, Muller-Parker GT, Muscatine L (1983) Temporal patterns of cell division in natural populations of endosymbiotic algae. Limnol Oceanogr 28:1009-1014

Wynne MJ (1998) A checklist of benthic marine algae of the tropical and subtropical western Atlantic: first revision. Nova Hedwigia Beih 116:1-155

Yonge CM (1936) Studies on the biology of Tortugas corals. 1. Observations on Maeandra areolata Linn. Carnegie Inst Washington, Pap Tortugas Lab 29:187-198

Zar JH (1984) Biostatistical analysis. Prentice-Hall, Englewood Cliffs, NJ

Zieman JC, Zieman RT (1989) The ecology of the seagrass meadows of the west coast of Florida: a community profile. Biol Rep 85(7.25):1-129

Submitted: June 10, 1999; Accepted: February 25, 2000 Proofs received from author(s): October 9, 2000 